\title{
The Implementation of Technology Acceptance Models in the Online Shopping Activity Through Social Media Instagram Among University of Sumatra Utara Students
}

\author{
Selwendri', Rumyeni ${ }^{2}$
}

\author{
Dept Business Administration, Faculty of Social and Politic, Universityof SumateraUtara,Medan-Indonesia ${ }^{1}$ \\ Dept Communication Science, Faculty of Social and Politic, Riau University, Pekanbaru-Indonesia ${ }^{2}$ \\ selwendri@usu.ac.id ${ }^{1}$,rumyeni.arum@gmail.com ${ }^{2}$
}

\begin{abstract}
Socialmedia used by the users for various purposes. Many features and complete attractive application made social media is easy to accepted by users. Instagram is one of social media much used among students, one of the purpose of its use is to do online shopping. Technology Acceptance Model or TAM by Davis (1988) assume that perceived easyof use and perceived usefulnessfactors influence upon acceptance or use of technology.The purpose of this research is to identify the influence of perceived easyof use and perceived usefulness by user on the actual usage of social media instagram in online shopping activityamong Sumatra Utara Universitystudents. This research uses the quantitative method by spreading questionnaire to 96 respondents. Data processed by using SPSS version 20.The research results show that both variables ofperceived easyof use and perceived usefulness was influence upon the actual usageof social media instagram in online shopping activity among University Sumatra Utara students. The Influence is 45,3 percent in medium category.
\end{abstract}

Keyword : Technology Acceptance Model (TAM), onlineshopping, social media, Instagram, Students

\section{INTRODUCTION}

The use of the media at marketing activity, also accompanied with the development of communication and information technology. Currently marketing have enter its phase which are affected by increasing the role of information technology that brings opportunities and market competition not only in the context of real world, but also on the virtual world.The development whichrelated to technology, have an impact at ease information that can be obtained by consumers to make the purchase decision, especially during the preparatory phase introduction of needs and information searching (karaatli et al. In graft, 2015).The development of the latest technology web 2.0 or known as social media.The emergence of social media has been presenting new business model based on social media with a characteristic of interaktivitas connectivity and customers where technology has an effect on how global network of marketers affecting consumers

According to data released by the internet service providers association (APJII) in 2016, shows that most frequently visited content by internet users is a web online shop, that of 82,2 million or 62 percent.Instagram is one of social media currently widely used by businesses in marketing their products and services.Factors that make instagram favored as media promotion is a feature sharing photos that were attributed to other social media like facebook and twitter

This research use the reception of technologymodel. (technology acceptance model).The reason for this is even though a model or other theory for example the theory of the act of dive and write different things ( theory of reasoned action ), and the undirected behavior planned manner ( theory of planned behaviour ) also can be used to predict and a detailed explanation of why users accepting or rejecting a an integrated information system for, but a model the reception of technology is simpler and acceptable as a strong model (venkatesh and morris, in anggraini, 2015)

A model of reception technology assumes that his conduct in the receipt of information technology was built over two ultimate confidence namely the perception of convenience of use (perceived ease of use) and perception of the benefits (perceived usefulness).The perception of the convenience use (perceived ease of use) is defined as a degree whereby a person believed that by the use of a technology is for going to get someone free of the attempt, while the perception of benefits (perceived usefulness) is defined as a measured manner where use of a technology will improving the performance the performance of someone (davis et al., 1989).In other words the use of technology believed will bring benefit to ones who uses it

Research on this topic in order to test the Technology Acceptance Model has been conducted. Anggraini (2015) with a title the perceptual effect to the convenience of use and perception from the usefulness against an intention to use and the actual use of the social networking services based location (study at student of economics and business faculty brawijaya university).The research results show that the perception to the convenience of use have a positive influence and significantly correlates with the use of intention, the perception of the usefulness have a positive influence and significantly correlates with the use of intention, and the intention of use have a positive influence and significantly correlates with the actual use the social networking services based location

Next research is hanggono et al.(2015) titled analysis of practice TAM (Technology Acceptance Model) in support of online business by using instagram social networking.The result showed that variable perseption ease of use has significant positive influence agains benefit perception, variable perceptionease of use having significant impact on the use of positive attitude, variable perceptionhave significant impact on the use of positive attitude, variable attitude having significant positive impact on use behavior, variable behavior to have positive significant impact on real conditions of the use of the system with value t count on sig 14.829. T worth 0,000 .

A number of studies that have been conducted before about testing TAM model, and the results will to come up with the phases of know the existence of the influence of inter variables reaches as high as, however from such influence it was not yet known, so this research purpose shall be set to continue research similar to those that had been done.Based on the above analysis in the background, 
the purpose of this study is to find the size of the the influence between the perception of the convenience of use (perceived ease of use) and benefits of that was felt to be (perceived usefulness) on the use of the actual (actual usage) social media instagran among the students of university of sumatra utara.

\section{Research Hypothesis}

H1 : Ease of use having significant influence on the use of actual social media instagram in online shopping activity among university sumatra utarastudents

H2 : Perception benefit felt having influence significant impact on the actual use of social media instagram in an online shopping activityamong university sumatra utarastudents

\section{RESEARCH METHODS}

This research used quantitative approach, namely an approach that emphasis on testing teori-teori or concept through measurement variable in metric or points and perform a procedure analysis of data with equipment statistics and aims to test the hypothesis.Based on its kind, this study is Explanatory Research. Explanatory Research used to analyze relation between one variable with other variables or how a variable affect other variables through the testing of hypotheses (sugiyono, 2012)

The population of the research is students of sumatra utara university ever do online shopping use the service of social media instagram. Number of university of sumatra utara students are already known, but number of students who had put up online shopping use the service of social media instagram still unknown, so that we can conclude that population in the research is infinite population and methods of sampling used in research is nonprobability sampling, where the opportunities or probability element of the population of being selected as the subject of sample (Sekaran 2006)

The sampling techniques in this research uses purposive sampling techniques, based on the sample types of design (judgmental sampling) particular consideration, where the sample collection limited to certain types of people can tell us desired based on particular consideration, (Sekaran, 2006). A characteristic to be owned by respondents consideration for the sample collection in this research is the student who ever shopped online through social media instagram at least once

Considering large of population and unknown number for sure, so samples to this research made on the opinion of Rao (in iswayanti, 2010) suggested that the in the determination of sampled if the population is large and the total number is not known that is by using the unknown populationformula. By using Unknown Formula Population so we canget respondent as many as 96 people.

\section{Operational definition variable}

1. Independent Variable (X1) perception ease of use social media instagram, referring to the extent of individual feel use a particular system easily comprehended and not difficult to be studied (Davis1989).In the context of social media, we can conclude that perception ease of use for individuals have the perception that does not require much effort in time or power to studies the use of social media instagram especially in the online shopping

2. Independent Variable (X2) The perception of the benefit that was felt by instagram social media users, refer to the extent to which individuals put his trust in the of particular system will improve the person work performance ( Davis 1989 ).Based on that definition, dimensions benefits can be seen from the perspective of improve their performance and made less work effective

3. Dependent Variable(Y) The actual use of social media, referring to the purpose of the activity of users in terms of access to social media instagram.Indicaotrin this section is comfort interact, like to use , and it is not boring.

\section{Analysis Data Technique}

Technique data analysis used in this research is multiple linear regression.Gujarati (2006) define regression analysis as the study of relation to variable those who are called explained variable and other variable as the Explanatory Variable. The first called also as variable independent and the second variables called also as variableindependenth.If the variable independent more than one, and multiple regression analysis called multiple linear regression. Multiple linear regression analysis used to see if the independent variable simultaneously influence the dependent variable .Multiple regression analysis in penenilitian is conducted by spss version on the 20 .

\section{RESULT AND DISCUSSION}

\section{Characteristics of Respondents}

Characteristics of respondents relating to data respondents identities useful to provide the research.The data is divided into age, sex, and semester

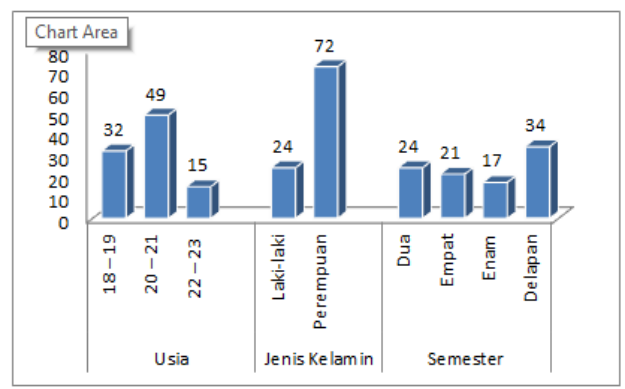

Picture 1:Characteristics of Respondents

Source : Processed researchers data, 2017

In Picture 1 it can be seen that respondents in this research the majority aged 20 and 21 years, total 49 person or 51 percent.Meanwhile aged 18 to 19 years as many as 32 people or 33.3 percent, and there are just 15 people or 14,4 percent aged 22 to 23 years.Seen of the characteristics of sex respondents in this research is dominated by women,total 72 person or 69,1 percent, while men as much as 24 people or 25 percent.Next, respondents in this research consisting of the students at the second semester to 8 semester.As in picture 1 , the majority of respondents in research is at 8 semester, with 34 person or 35.4 percent, the second is the second semester by the number of 24 respondents or 25 percent, while semester 4 and 6 each were 21 people and 17 people or 21,9 and 17,7 percent .

\section{The use of social media instagram}

The use of social media instagram gives descriptions of how respondents during this consume social media instagram in their dailylife.In picture 2 can be seen that the majority of respondents have used instagram within 3 until 4 years, there were a total of 47 percent of all respondent.While second position is respondents who has the use instagram during 1 up to 2 years. there were a total of 32 percent.Been disclosed in the research this shows that quite number of respondents who has the use of social 
media instagram within the period of 5 to 6 years about 11 percent. And the rest are made who has the use of instagram for more than 6 years and less than one year, the amount as many as 5 percent from the the total respondents.

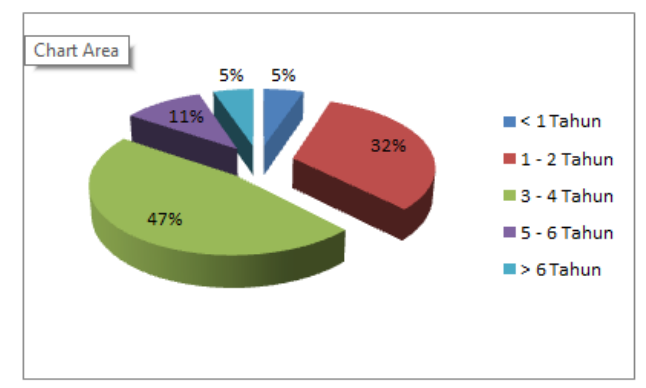

Picture 2 :A period of time have used social media instagram Source : Processed researchers data, 2017

Dependence and craze of someone to social media can be seen from the time they spend to access the media.Picture 3 below show data about the duration of respondents to access social media instagram in a day.In the picture it is evident that average respondents spent social media instagram between 1 until 6 hours a day.There are 34 percent of respondents access social media instagram for 1 to 3 hours, and 31 percent between 4 to 6 hours

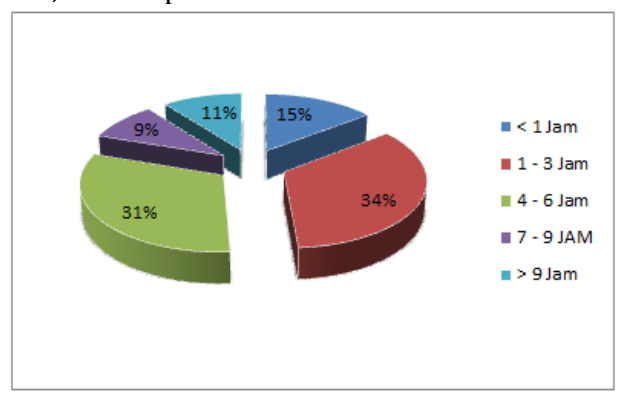

Picture 3 :Duration access social media instagram in a day Source : Processed researchers data, 2017

Online shopping could told a trend that operates by people from all levels since the incoming of media sosial.This activity favored because many facilities offered by online shop and features of social media itself.In this study, the majority have done online shopping through social media instagram as many as 1 to 2 times. 27 percent of respondents have online shopping through instagram about 3 to 4 times.Meanwhile many respondents have online shopping through instagram a total of more than 6 times about 16 percent, and only 9 percent the respondents who have online shopping through instagram about 5 and 6 times.From this data can be concluded that more than half of the respondents buy online through instagram more than 3 times.

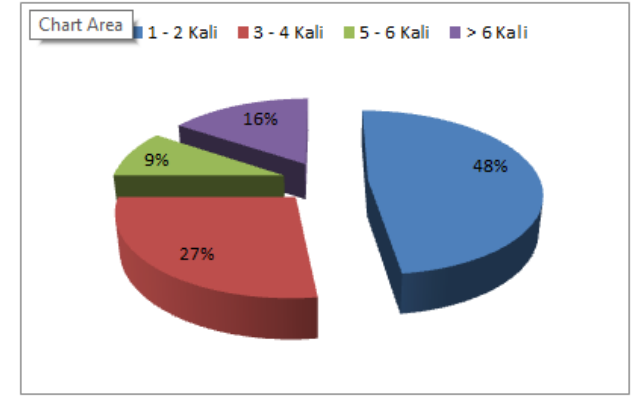

Picture 4: Many online shopingthat ever been used Source : Processed researchers data, 2017

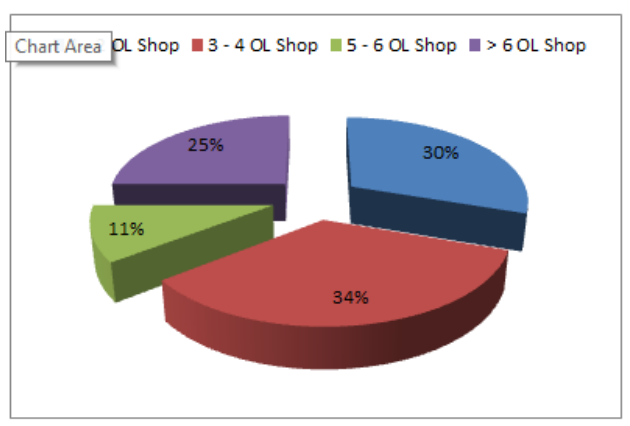

Picture 5: The number of accounts instagram online shop followed

Source : Processed researchers data, 2017

Instagram become social media which much used by online shop in marketing product or services.The power of instagram company which is supported by with the qualities of an image that is either made product offered was more attracted.In the picture 5 above it can be seen that 34 percent of respondents had following as many as 3 until 4 online shop. 30 percent of respondents follow 1 until 2 online shop, and pull it a quarter of the number of respondents of the study this follows more than 6 online shopaccount

There are numerous types of products and services sold through social media instagram, such as a product fashion, culinary, cosmetics, accessories, and many others.This research result indicates that the dominated and most often purchased by respondents is fashionproductwith 75 percent of the overall respondents. Thisfashion products are clothes, shoes, bag, and others. Second position is cosmetics product and the body care.As many as 12 percent of respondents buy the products through social media instagram.other kind of products such as a product culinary, accessories, and other not much bought by respondents, the number who buy the products through instagram each is not more than 6 percent 


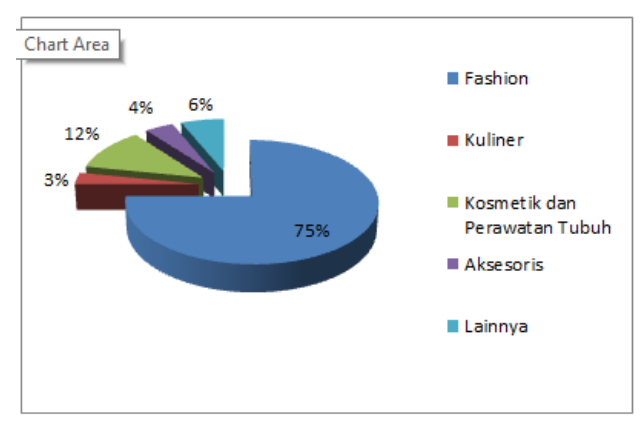

Picture 6 :The kind of product that most often bought through social media instagram

Source : Processed researchers data, 2017

Perception ease of use of social media instagram in an online shopping activity Davis (1989) said that perceived ease ofuse is a levels by which a person believe that the use of a particular system can reduce a person in business working on something.This means that a person using the media to support their activity because of they belief that the use of these forms of media easy and able to help them to make it easier for an effort to obtain something what they came there for

Instagram as one social media much used by consumers or online shop in transaction believed to have ease factor as asserted in the model TAM by Davis (1989).The response of respondents were presented in table 3 below shows that the majority of respondents said agree that instagram have easy usage in support of online shopping.They have the perception that instagram are believed to have features easy to learn. understandable, flexibility and accessible, and instagram made users proficient in online shopping.

Table 1: Perception ease of use

\begin{tabular}{|l|c|c|c|c|c|}
\hline $\begin{array}{l}\text { The perception of to the convenience of the } \\
\text { the use of instagram in any securities } \\
\text { activities according to the online budget for } \\
\text { routine expenses in }\end{array}$ & \multicolumn{5}{|c|}{ Frequency (\%) } \\
\hline \multicolumn{1}{|c|}{} & ISD & ID & II & IA & ISA \\
\hline $\begin{array}{l}\text { Features instagram easier leamed than other } \\
\text { social media }\end{array}$ & 0 & 13,5 & 1 & 60,4 & 25 \\
\hline $\begin{array}{l}\text { Exposure to a menu in instagram are easy to } \\
\text { understand }\end{array}$ & 0 & 4,2 & 4,2 & 70,8 & 20,8 \\
\hline $\begin{array}{l}\text { Instagram being flexible and easily accessible } \\
\text { way to so that it can help making transactions }\end{array}$ & 1 & 9,4 & 17,7 & $\mathbf{5 2 , 1}$ & 19,8 \\
$\begin{array}{l}\text { online spending will go to war with you } \\
\text { wherever and anytime }\end{array}$ & & & & & \\
\hline $\begin{array}{l}\text { Instagram made users proficient do online } \\
\text { shopping }\end{array}$ & 2,1 & 19,8 & 25 & $\mathbf{4 2 , 7}$ & 10,4 \\
\hline
\end{tabular}

Source : Processed researchers data, 2017

Of various ease contained in social media instagram, exposure to the menu instagram comprehensible become answer to the most chosen respondents. alternative answers agree, namely 70,8 percent.Compared with other social media, instagram have a menu relatively simple.Menumenu in instagram including picture, video, geotagging, columns comment, hastag (\#), and arroba (@).Simplicity menu is the reason that makes respondents own perception that instagram is social media ease of use in supporting activity online shopping

The perception of the benefit that was felt at social media instagram online shopingactivity

Thompson (1991) said that an individual will move into higher technology if the person is well aware of a benefit from the usefulness of it.Benefit that was felt in the use of social media its industrial activity among others to improve their working performance and make the most powerful work more effective.

Table 2 below displays comments about the perception of respondents about instagram benefits in an online shoppingactivity.The majority of respondents in this research disagree that they felt the benefit in social media instagram when they do online shopping. Most respondents in this research said agree namely 68.8 percent in the manifestation of the online expenditure through social media instagram was very beneficial because are saving the time.It cannot be denied that excess most dominant owned by social media in supporting the activity of online shopping is its ability in serving consumers through the medium, it not worth come to directly from store merchandise is sold .With the excess of this, consumers can saving more money and time because can do deals in wherever they may be, and can be having a deal in the sidelines of their activity.Consumers do not have to spend some time specialized to conduct the activity of shopping, as if conventional shopping in come to shops, the market, other and shopping centers.

Table 2: Perception benefits instagram in an activity expenditure online

\begin{tabular}{|c|c|c|c|c|c|}
\hline Perception instagram benefits felt in the & \multicolumn{5}{|c|}{ Frekuensi (\%) } \\
\hline & ISD & ID & II & IA & ISA \\
\hline $\begin{array}{l}\text { Shop: Chart Area pugh instagram not time } \\
\text { consulums anu uvo not affect the primcipal } \\
\text { activity, that achievement and eager to study } \\
\text { undisturbed }\end{array}$ & 1 & 15,6 & 15,6 & 54,2 & 13,5 \\
\hline $\begin{array}{l}\text { Onlime spending through instagram was very } \\
\text { beneficial because are saving the time }\end{array}$ & 0 & 5,2 & 10,4 & 68,8 & 15,6 \\
\hline $\begin{array}{l}\text { Online spending through instagram was very } \\
\text { beneficial because in alleviating the cost }\end{array}$ & 0 & 22,9 & 22,9 & 43,8 & 10,4 \\
\hline $\begin{array}{l}\text { By using instagram make consumers can be } \\
\text { more quickly get information goods latest } \\
\text { needed }\end{array}$ & 0 & 5,2 & 13,5 & 56,3 & 24 \\
\hline $\begin{array}{l}\text { Online spending through instagram is very } \\
\text { efficient. so that users can focus more on } \\
\text { leaming and do their tasks }\end{array}$ & 1 & 20,8 & 22,9 & 49 & 6,3 \\
\hline
\end{tabular}

Source : Processed researchers data, 2017

Besides saving time, social media instagram can also helps a user to increase their achievement and eager to study because with online through Instagram, they will not need a lot of time to do a lot of task and the principal activity will not be affected.By the use of instagram has caused consumers can be more quickly get the information that they need and latest goods, this makes consumers more cost efficient, and can be is focused for take more time to learn and do their tasks

\section{The actual use social media in online shopping}

The actual use (actual system usage) are the condition of the real the utilization of the system (Davis, 1989) .An individual will be satisfied devised a system if bear in mind the certainty that the system is easy to use and will raise their productivities, that which is reflected from real conditions of the use of (Natalia Tangke, 2004).In this research the actual use social media instagram in any securities activities according to the online budget for routine expenses is divided into three city indicators of the quality of like convenience be able to interact with, like to use, and it is not boring.

Tabel 3 Below provides actual about the use of university sumatra utarastudents in the use of social media instagram when they commit the activity of online shopping. The average student who be the respondents in this research said agree that they use instagram as a medium to 
online shop because the comfort of interacting with.The availability of features a column comments make respondents feeling easily to be able to interact and communicate with the dealer and others buyers also.Comfort interact was also based on the existence of other features chating features that made them feel easier to ask further surrounding point out a product they were interested in it.The chat features has caused consumers it is usually felt more comfortable to ask more detailed about products or the do bargain price. The seller is usually would prefer explain their products especially surrounding the price if it is conducted through private message

Table 3: The actual use social media instagram online expenditure in an activity

\begin{tabular}{|c|c|c|c|c|c|}
\hline \multirow[t]{2}{*}{ The actual use social media instagram } & \multicolumn{5}{|c|}{ Frequency $(\%)$} \\
\hline & ISD & ID & II & IA & ISA \\
\hline \multicolumn{6}{|l|}{ Comfort interact } \\
\hline $\begin{array}{l}\text { Respondents access instagram to interact with online } \\
\text { shop }\end{array}$ & 5,2 & 26 & 16,7 & 47,9 & 4,2 \\
\hline $\begin{array}{l}\text { Features column comments easier to imteract and } \\
\text { communicate with the seller and buyers another }\end{array}$ & 3,1 & 12,5 & 18,8 & 62,5 & 3,1 \\
\hline $\begin{array}{l}\text { The faatures chat easier to ask further about products } \\
\text { posted online shop on the wall }\end{array}$ & 0 & 4,2 & 14,6 & 70,8 & 10,4 \\
\hline \multicolumn{6}{|l|}{ Like to use } \\
\hline $\begin{array}{l}\text { Instagram favored to shop online for his pictures of } \\
\text { products and its risul monitor interesting }\end{array}$ & 0 & 4,2 & 13,5 & 66,7 & 15,6 \\
\hline $\begin{array}{l}\text { Instagram in favor and goodwill with order to make } \\
\text { their purchases online because of the arvalability of } \\
\text { video the product of those who make a display and } \\
\text { features products more so clearly be seen }\end{array}$ & 1 & 8,3 & 14,6 & 56,3 & 19,8 \\
\hline $\begin{array}{l}\text { Instagram favored to used as a medium shopping } \\
\text { online because of the availablity of features hastag } \\
\text { \#) that is easy to consumers to look for mtended } \\
\text { products }\end{array}$ & 2,1 & 8,3 & 10,4 & 59,4 & 19,8 \\
\hline $\begin{array}{l}\text { Instagram more favored to used in performing } \\
\text { expenditure onlime than the media other social }\end{array}$ & 2,1 & 21,9 & 12,5 & 52,1 & 11,5 \\
\hline \multicolumn{6}{|l|}{ not stodgy } \\
\hline $\begin{array}{l}\text { Instagram allows online shop can to posing his } \\
\text { latest products all the fime that varies so as to make } \\
\text { consumers not get bored }\end{array}$ & 1 & 1 & 10,4 & 66,7 & 20,8 \\
\hline $\begin{array}{l}\text { View photos product by good quality products made } \\
\text { look better }\end{array}$ & 1 & 3,1 & 11,5 & 65,6 & 18,8 \\
\hline
\end{tabular}

Source : Processed researchers data, 2017

The research also indicates that the majority of university sumatra utarastudents love to use instagram in an activity online shopping.Factor that has an influence dominant caused for his pictures of products and a visual display in instagram interest to those.In addition is also due to the availability of features hastag (\#) which make our customers look for intended products.Next respondents also liked instagram as a medium shopping online because of the presence of video features or also called with vidgram, who make a display products show up more clearly

Other indicators in the actual use social media instagram is not boring. 65 percent more university sumatra utarastudents said agree that instagram not boring in supporting their online shopping activities.Instagram was considered boring because instagram allow online shop post his latest produk-produk all the time, and display product by good quality products made looking attractive

\section{Test Research Instruments}

Test an instrument done in research there are two, namely the validity and reliability.Test validity is testing to item-item statement.Test validity done to testing whether research instruments used in research is right.A items said valid when the correlation across a score of the grains with the score total positive and larger than 0.3 (sugiyono, 2012).Table 4 presents the results of the validity research instruments.

Table 4: Result of validity test

\begin{tabular}{|c|c|c|c|}
\hline Variabel & $\begin{array}{c}\text { Indikato } \\
\mathbf{r}\end{array}$ & $\begin{array}{c}\text { Koefisie } \\
n \\
\text { Korelasi }\end{array}$ & $\begin{array}{c}\text { Keteranga } \\
\text { n }\end{array}$ \\
\hline \multirow{4}{*}{$\begin{array}{l}\text { Perception } \\
\text { ease of use } \\
(\mathrm{X} 1)\end{array}$} & $\mathrm{X} 1.1$ & 0,577 & Valid \\
\hline & $\mathrm{X} 1.2$ & 0,489 & Valid \\
\hline & $\mathrm{X} 1.3$ & 0,559 & Valid \\
\hline & $\mathrm{X} 1.4$ & 0,549 & Valid \\
\hline \multirow{5}{*}{$\begin{array}{l}\text { The } \\
\text { perception of } \\
\text { the benefit } \\
\text { that was felt } \\
\text { (X2) }\end{array}$} & $\mathrm{X} 2.1$ & 0,594 & Valid \\
\hline & $\mathrm{X} 2.2$ & 0,543 & Valid \\
\hline & $\mathrm{X} 2.3$ & 0,559 & Valid \\
\hline & $\mathrm{X} 2.4$ & 0,300 & Valid \\
\hline & $\mathrm{X} 2.5$ & 0,497 & Valid \\
\hline \multirow{9}{*}{$\begin{array}{l}\text { The actual use } \\
\text { (Y) }\end{array}$} & $\mathrm{Y} 1$ & 0,393 & Valid \\
\hline & Y2 & 0,390 & Valid \\
\hline & Y3 & 0,306 & Valid \\
\hline & Y4 & 0,508 & Valid \\
\hline & Y5 & 0,677 & Valid \\
\hline & Y6 & 0,441 & Valid \\
\hline & Y7 & 0,656 & Valid \\
\hline & Y8 & 0,447 & Valid \\
\hline & Y9 & 0,407 & Valid \\
\hline
\end{tabular}

Source : Processed researchers data, 2017

Reliability test is a testing to see the extent to which the measurement result remain consistent if conducted measurement twice or over against similar symptoms using same measuring instrument (sugiyono, 2012).A measurement reliable if it has kooefesien croanbach alpha same or more than 0,60.Reliability test carried out and served in table 4 indicate that all research instruments of the coefficient cronbach's alpha more than 0,60 .This could be said that all instrument can be used to do research

Table 5: Result of Reliability test

\begin{tabular}{|l|l|c|c|}
\hline No. & \multicolumn{1}{|c|}{ Variabel } & $\begin{array}{c}\text { Cronbach's } \\
\text { Alpha }\end{array}$ & Keterangan \\
\hline 1 & $\begin{array}{l}\text { Perception } \\
\text { ease of use }\end{array}$ & 0,748 & Reliabel \\
\hline 2 & $\begin{array}{l}\text { The } \\
\text { perception of } \\
\text { the benefit } \\
\text { that was felt }\end{array}$ & 0,731 & Reliabel \\
\hline 3 & The actual use & 0,780 & Reliabel \\
\hline
\end{tabular}

Source : Processed researchers data, 2017

\section{The results of the linear regression multiple}

To test hypotheses 1 and 2, test linear regression multiple has been used to identify the effects or contribution every independent variable which includes perception ease the use of and perception advantages on variables dependent namely, the use of actual social media instagram.

Table 6: The results of the linear regression multiple

\begin{tabular}{|c|c|c|c|c|c|}
\hline \multirow{3}{*}{\begin{tabular}{|l|} 
Model \\
Chart Area \\
\end{tabular}} & \multirow{2}{*}{\multicolumn{2}{|c|}{$\begin{array}{l}\text { Unstandardized } \\
\text { Coefficients }\end{array}$}} & \multirow{3}{*}{$\begin{array}{c}\text { Standardized } \\
\text { Coefficients } \\
\text { Beta }\end{array}$} & \multirow[t]{3}{*}{$\mathrm{t}$} & \multirow[t]{3}{*}{ Sig. } \\
\hline & & & & & \\
\hline & B & $\begin{array}{l}\text { Std. } \\
\text { Error }\end{array}$ & & & \\
\hline \multirow{3}{*}{$\begin{array}{l}\text { (Constant) } \\
\text { Perception ease of } \\
1 \text { use } \\
\text { The perception of } \\
\text { the benefit that was } \\
\text { felt }\end{array}$} & 13,972 & 2,303 & \multirow{3}{*}{.450} & 6,067 & \multirow{3}{*}{\begin{tabular}{|l|}
, 000 \\
, 000 \\
, 006
\end{tabular}} \\
\hline &, 783 &, 177 & & 4,414 & \\
\hline &, 427 &, 153 & & 2,795 & \\
\hline
\end{tabular}

Source : Processed researchers data, 2017

The results of data processing of multiple regression obtained the number as follows 
1. $\quad$ Konstanta (a) $=13,972$

2. Koefisien variabel $\mathrm{X}_{1}\left(\mathrm{~b}_{1}\right)=0,783$

3. Koefisien variabel $\mathrm{X}_{2}\left(\mathrm{~b}_{2}\right)=0,427$

Thus may be prepared the regression equation is as follows:

$$
Y=13,972+0,783 X_{1}+0,427 X_{2}
$$

According to the equation regression above, interpretation of each coefficients variable is as follows:

a. A. constant of 13,972 , are defined that the variable $\mathrm{X} 1, \mathrm{X} 2$ fixed or not change so actual use social media instagram in an activity online shopping among university sumatra utarastudents will of 13,972 points.

b. The coefficients variable $\mathrm{X} 1$ ( $\mathrm{b} 1$ ) as much as ( 0,783 ), it means variable perception at ease the use of social media intagram can make increasing use of actual than social media instagram upon an activity online shopping among university sumatra utarastudents because proven that it's influence.

c. $\mathrm{X} 2(\mathrm{~b} 2)$ as much as 0,427 , this means that variables the benefits of the social media instagram that was felt to be in any activities according to the online shopping affecting the use of social media instagram on students from universitas sumatrautara

\section{The results coefficient determination test}

The coefficients determinationtest $\left(\mathrm{R}^{2}\right)$ aims to know how big the ability of variable independent to explain variableDependenth. $\mathrm{R}^{2}$ used to measure the magnitude of contributions together of variable independent against variabledependenth.The coefficients determination test $\left(\mathrm{R}^{2}\right)$ can be found by using linear multipleregression analysis.The coefficients determination is indicating exactness the regression equation is that estimated of a sample of collected value $\mathrm{R}^{2}$ ranged from $0<1$ or $0<R<1$.If $\mathrm{R}^{2}$ the bigger (approaching 1), so contributions variable Independethtogether against variables Dependenth is increasing.

\section{Table 7: Coefficient determination test results}

\begin{tabular}{|r|r|r|r|r|}
\hline Model & $\mathrm{R}$ & $\mathrm{R}$ Square & $\begin{array}{r}\text { Adjusted R } \\
\text { Square }\end{array}$ & $\begin{array}{c}\text { Std. Error of the } \\
\text { Estimate }\end{array}$ \\
\hline 1 &, 673 &, 453 &, 441 & 3,392 \\
\hline
\end{tabular}

Source : Processed researchers data, 2017

From the table above it can be seen the value of $\mathrm{R}^{2}$ is 0,453 ( 45,3 \% ).It means, variansi variable Dependenththat can be described as much as $45,3 \%$ while the rest $54.7 \%$ described by other variables that not researched by this research.Based on the categories interpretation of the value of the coefficient determination by sugiyono (2012) said the figure was included in the category of being/moderate.

\section{Uji t}

The testing of hypotheses first and second used test $t$. test $t$ done by comparing $p$ value with the $\alpha$ value.If $p$ value $<\alpha$, so significant .If $p$ value $>\alpha$, so insignificant .From the Tests carried out it can be seen that:

1. $\mathrm{P}$ Value $\mathrm{X}_{1}(0,000)<\alpha(0,05)$ This indicates hypothesis 1 proven, it means is the significant between ease the use of social media instagram on the use of actual social media instagram in online shopping activityat university sumatrautarastudents

2. $\quad$ value $X_{2}(0,006)<\alpha(0,05)$. This indicates hypothesis second proven .It means is the significant between benefits social media instagram felt on the use of actual social media instagram among university sumatrautarastudents

\section{CONCLUSION AND RECOMMENDATIONS}

Instagram be a pleasant easily accessible to users in the online shopping.The perception of ease of use and advantages, possessing significant influence on the actual use of social media.Social media instagram is easy to be used in online shopping activity among the students of university sumatra utaracaused by the feature that easy to learn, the menu intelligible, and fleksibilities so users are easy to commit online shopping anywhere and at their own time.Ease is that they became proficient in online shopping. Next, instagram also considered bring more benefits for those who favor activity online shopping.With online shopping through instagram they are saving time and money, get goods they need, information they need, and more efficient that they could have been more use time to focus on their main task learning and carried out college.Satisfaction the use of social media instagram in an activity online shopping among the students of sumatra utara university shown by the actual use of media that's is comfortable to interact, like to use the media, and not boring.From the test determination known that the perception ease of use and advantages contributed influence of 45,3 percent against the actual use social media instagram in an activity online shopping among the students of university sumatrautara, or included in medium category.

Although instagram as a media online shopping proved easy in use and useful, but advised for users to be more careful with - do online shopping and become a smart buyer.Shop in accordance with their needs, avoid the nature of consumerism, and conscientious before deciding to buy.For the next interested to examine for the same theme, suggested to add other variables and research differentconsumer groups.

\section{REFERENCES}

APJII. The statistics internet users indonesia of 2016 . http://isparmo.web.id/2016/11/21/data-statistikpengguna-internet-indonesia-2016/

Anggraini, Rila. 2015. The perception ease of use and perception usefulness of intention to use and actual use service social networking site study based ( the students school of economics and business university Brawijaya Malang). Jurnal Ekonomi dan Bisnis. Vol 20 (1) $1-52$

Chin W Wynne, Todd Peter. 1995. "On The use Usefullness, ease of use of structural equation Modeling in MIS Research : A note of Caution ". Management Information System Quarterly, 21(3)

Davis, F.D. 1989. Perceived usefulness, perceived ease of use, and user acceptance of information technology. MIS Quarterly. Vol.13(3): 319-340.

Destiana, Ika, Ali Salman \& Mohd. Helmi Abd. Rahim. 2013. The reception of social media: of the study in the 
council of universiti in palembang. Malaysian Journal of Communication. Vol. 29(2): 125-140

Hanggono, Aditya Ari, Siti Ragil Handayani \& Heru Susilo. 2015. Analysis of practice tam ( technology acceptance model ) in support of online business by using instagram social networking. Jurnal Administrasi Bisnis. Vol. 26 (1) : 1 - 9

Kriyantono, Rahmat. 2010. Teknik Praktis Riset Komunikasi. Jakarta: Kencana

Paramitha, Cindy Rizal putri. 2011. The promotion of factor analysis based social media of the decision on customers in culinary sector.Thesis. Ekonomis-1. Fakultas Ekonomi Universitas Dipenogoro

Sekaran, U., 2006, Research methodology for business, the fourth, the second book, Jakarta: Salemba Empat.

Sugiyono. 2012. Research methodology quantitative qualitative and $r \& d$.Bandung: Alfabeta 